\title{
Investigation of Microfacies-Electrofacies and Determination of Rock Types on the Aptian Dariyan Formation NW Persian Gulf
}

\author{
Katayoon Rezaeeparto', Hossein Rahimpour Bonab ${ }^{2 *}$, Ali Kadkhodaie ${ }^{3}$, Mehran Arian1, \\ Elham Hajikazemi ${ }^{4}$ \\ ${ }^{1}$ Department of Geology, Science and Research Branch, Islamic Azad University, Tehran, Iran \\ ${ }^{2}$ Department of Geology, Tehran University, Tehran, Iran \\ ${ }^{3}$ Department of Geology, Tabriz University, Tabriz, Iran \\ ${ }^{4}$ Department of Geology Studies, Offshore Oil Company, Tehran, Iran \\ Email: "hrahimpor@gmail.com
}

Received 14 November 2015; accepted 15 December 2015; published 28 January 2016

Copyright (C 2016 by authors and Scientific Research Publishing Inc.

This work is licensed under the Creative Commons Attribution International License (CC BY).

http://creativecommons.org/licenses/by/4.0/

c) (i) Open Access

\begin{abstract}
Dariyan (Shuaiba) Formation is one of the main reservoir units in the Persian Gulf and South Western Iran. The microfacies and depositional environment of this formation is been investigated in the current study and influencing factors in reservoir characteristics have been discussed for Dariyan reservoir in the Soroush oil field. Facies analysis conducted on core and cutting samples indicated that Dariyan Formation is mainly deposited on a carbonate ramp setting with a shallow intra shelf basin. In addition, it has been demonstrated that facies changes reflect the main controls of the tectonic and climate (sea level fluctuations) during the deposition of these sediments. To determine the reservoir unites in this formation, 5 electrofacies were determined by neural network method that it is using different petrophysical logs (i.e. GR, PHIE and SWE). Using rock typing as the best way to establish an association between the various collected data (e.g. logs and cores) and geological descriptions 4 hydraulic flow units or rock types, determined on the basis of the Flow Zone Indicator (FZI) method in the Dariyan Formation of the Soroush field. Establishing a correlation between microfacies and rock types, the carbonate zones with moderate to good reservoir properties and also the intervals with the highest reservoir quality were determined.
\end{abstract}

\section{Keywords}

Dariyan Formation, Micro Facies, Soroush Field, Rock Types

\footnotetext{
${ }^{*}$ Corresponding author.
}

How to cite this paper: Rezaeeparto, K., Bonab, H.R., Kadkhodaie, A., Arian, M. and Hajikazemi, E. (2016) Investigation of Microfacies-Electrofacies and Determination of Rock Types on the Aptian Dariyan Formation NW Persian Gulf. Open Journal of Geology, 6, 58-78. http://dx.doi.org/10.4236/ojg.2016.61007 


\section{Introduction}

The lower Cretaceous Orbitolina limestone of the Dariyan (Shuaiba) Formation is one of the well-known and important reservoirs in many oil fields in Southewestern Iran and the Persian Gulf [1]. The name "Dariyan Formation" was taken after the section measurements of Gadvan Rocks, located in the northern parts of the Dariyan town in the Northeast of Shiraz.

This lower Cretaceous formation is equal to Shuaiba, and it is among the formations of Khami group (higher Khami) with carbonate lithology. The formation is also important in the sense that it is categorized as the main reservoir of so many fields in the south western Iran. In general, due to its importance in petroleum geology, the study of Dariyan Formation has been always considered as an area of interest for researchers whose studies have indicated the high importance of the reservoir. In the type section, the formation consists of 286.5 meter thick brown-gray limestone, bedded to a massive rough and rocky that is an index of having a great Orbitolina Aptian. The lower boundary of Dariyan is correlated with the gradual formation of Gadvan. The lower boundary, however, is severely eroded by Kazhdumi and oolitic and then, it is separated from Kazhdumi by glauconite layers. A regional unconformity, representing erosion or non-deposition of the middle Aptian section, marks the contact between Dariyan and the overlying Kazhdumi Formation in this area [2] [3]. At the contact, a surface of strongly iron-stained, sandy, and glauconitic sediments is found [4].

According to the recent discussions on the expanding fields and new discovery of accessory reservoirs, especially since the Khami group became one of the main targets in this project, oil industry experts have paid close attention to investigation of the lime sediments in Dariyan Formation. A huge body of the work has been conducted to address the microfacies and sedimentary environments and the roles they play as the controlling factors of reservoir quality. What follows is intended to name some of the projects in the region: James and Wynd [1] were the pioneers to divide Khami group into five formations: Surmeh, Heath, Fahliyan, Gadvan, and Dariyan. Shemirani, et al., [5] conducted a lithostratigraphic and biostratigraphic study on Dariyan and Kazhdumi formations in the South West of Iran. Rahimpour Bonab, et al., [6] studied the Reservoir's characteristics and sedimentary environment of Dariyan Formation in Persian Gulf (Persian Gulf from the Strait of Hormuz to the extreme northwest). Lasemi and Siyahi [7] re-conducted their study in 2005 to show the sequence stratigraphy and sedimentary environment of Dariyan Formations in the southern part of Dezful Embayment (Khami section and well Sulabadar 3). Poorbagher, et al., [8] compared the anticline Aneh and Chelingar Well Ш in Dariyan Formation microfacies. Adabi and Abbasi [9] analyzed the diagenetic history of Black mountain in the North East of Shiraz and Sabzpooshan Well I, based on petrographic and geochemical characteristics of Dariyan Formation. Amiri, et al., [10] studied sedimentary environments and sequence stratigraphy of Dariyan Formation in South Pars oilfield. Saadi Rad, et al., [11] investigated syndepositional and post depositional history of Dariyan formation in Azadegan oilfield.

In this study, microfacies, depositional environment and electrofacies have been investigated in detail to determine the reservoir quality of Dariyan Formation in Soroush oilfield in the Persian Gulf.

Soroush oilfield, located in Persian Gulf basin is one of the significant fields of the oil reserves in this region. This oilfield was discovered in 1962 and well S2 as the first drilled well, came into operation with maximum daily production of 14 thousand barrels from Burgan layer. This field has an area of approximately $260 \mathrm{Km}^{2}$ and which is located at a distance of $83 \mathrm{~km}$ southwest of Kharg Island. Due to damages incurred during the war, oil production of the field was completely re-launched and is now being developed. It is estimated that, Soroush has 7 billion and 500 million barrels of oil in place and also it is planned to develop 500 million barrels of recoverable oil exploitation. Therefore, reconstruction and development facilities of this field are critical. Soroush oilfield produces sweet and heavy oil, having an API gravity of 20 - 22. This Figure 1 shows the location of Soroush oilfield in Persian Gulf basin.

The name of this formation is taken from a village located in the south of type section. In the past, there were other names such as Orbitolina limestone, Aptian-Albian lime, and finally Khami lime adopted for the formation. The Dariyan Formation type section is measured in Gadvan Mountain, which is located in the northern part of Dariyan village. Geographical coordinates of the incisions are 51, 37, $29=\mathrm{N}$, and 12, 57, $52=\mathrm{E}$. In the type section, the formation consists of 286.5 meters of thick brown to gray lime, that is bedded to a rough, outstanding layer, attributed to the shallow marine environments where there is an abundance of Orbitolina. Also, the remains of retail Rudists could be simply detected all over the formation. The age of limestone found in Dariyan Formation is Aptian [1]. The Dariyan Formation has been reported to contain oil in Salman, Reshadat, Resalat, and Foruzan oilfields, and to have the potential of containing oil in Balal, Golshan, Ferdowsi, Norooz, 


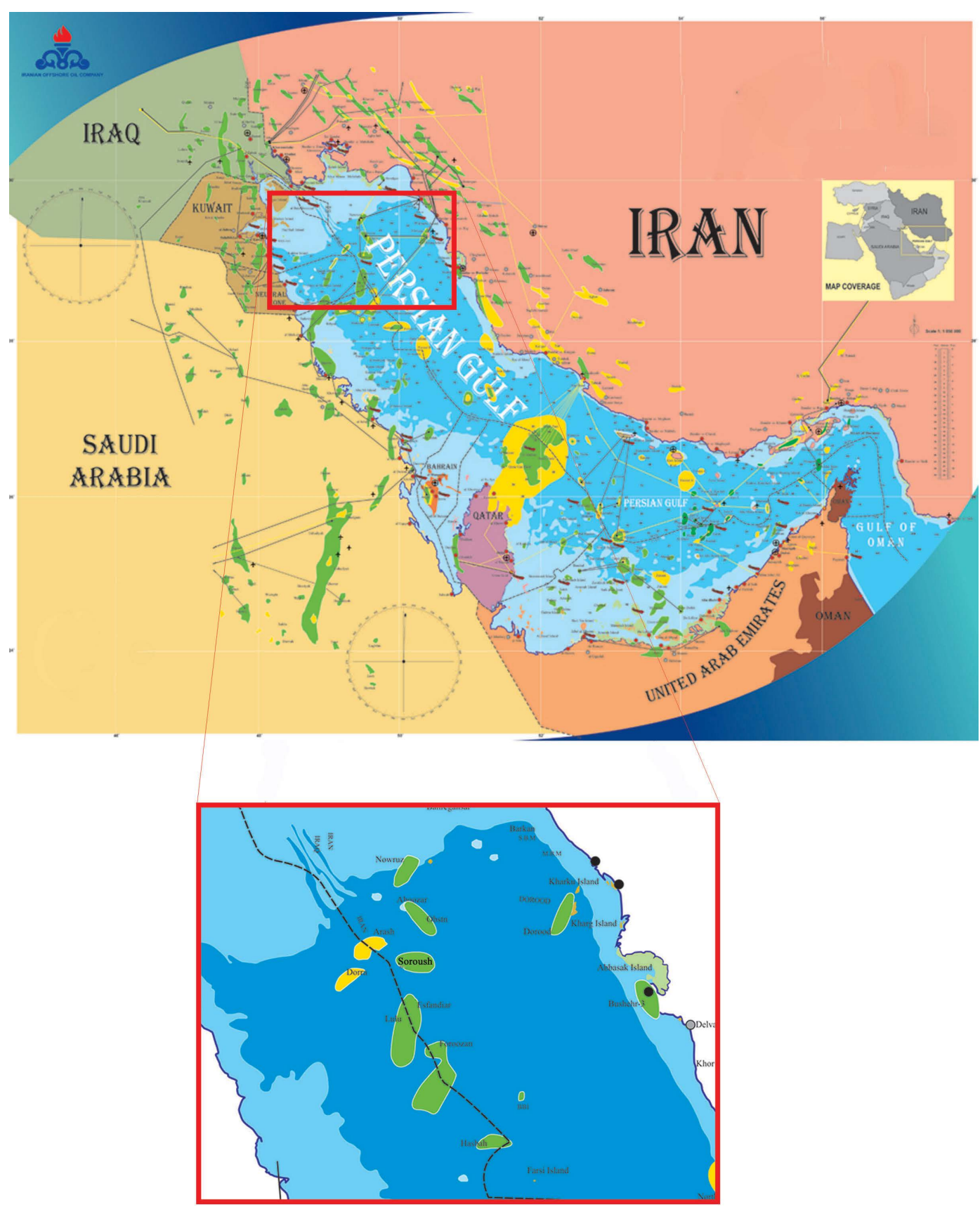

Figure 1. Location of Soroush Oilfield in Persian Gulf basin.

and Soroush oilfields. Furthermore, there are hydrocarbonic reserves in the oil fields located in southern Dezful Embayment. As applied to the Shuaiba Formation, the Dariyan Formation is extended to the neighboring countries as described below:

1) The Shuaiba Formation in the south of Iraq: a $79.8 \mathrm{~m}$ thick type section was detected in Zobair Well $\amalg$ in the Shuaiba Formation. These Carbonates are limited to a shallow to medium marine environment with a destructive reserve. The lower boundary is consistent with Zobair Formation, while the upper boundary is inconsistent with Nahr Omr Formation [12].

2) The Shuaiba Formation in Bahrain: in its base, the formation consists of argillitic limestone replaced by the fine limestone with fine porosity at the top. In this section, there is a plenty of recrystallized limestone, and occasional cases of the dolomitic limestone covered with a fine porosity at the top [12]. 
3) The Shuaiba Formation in the United Arab Emirates: the above formation shows an internal shelf basin and a stable Craton shelf margin. A continental slope facies, a typical (almost) dense wackestone/mudstone argillitic limestone, and a shale with some grain supported sediments were deposited in the Formation [13].

4) The Shuaiba Formation in Qatar: Around $132 \mathrm{~m}$ thick, Shuaiba Formation in Qatar bears resemblance to that of the United Arab Emirates. In Qatar coastal line, it consists of fine-grained limestone with fine porosity and organic debris that form a part of recrystallization. Sometimes, dolomitization is in the form of offshore sedimentary cycle that includes four units [12].

\section{Materials and Methods}

At first, the recovered core samples are gamma scanned for depth matching with well logs (GR log). After core-log depth matching, the cores have been studied and logged sedimentologically in two steps. The first step was a quick-look analysis (macroscopic studies) of the un-slabbed cores. All drilled cores have a diameter of 10 cm (4 inches), makes it possible to see small-scale sedimentary and diagenetic features (such as stylolites, lamination and etc.) and facies changes. Based on the quick-look sed.-log and client comments, the cores were sampled closely (with $0.3 \mathrm{~m}$ spacing) using the plugging method and core chips sampling. Nearly 550 samples were taken in this order. Standard thin sections prepared from these samples were used for petrographic analysis.

During the second step, detailed microfacies and palaeoenvironmental analysis have been done on thin sections to interpret the depositional environment of the Dariyan Formation. Microfacies criteria developed mainly by Wilson (1975) and Flugel (1982 and 2004) have been used in this study for defining the microfacies and Dunham classification system [14] was used for naming context facies. Particular attention was paid to lithology, texture, faunal and allochems content, bedding surfaces, pore types and diagenetic processes (especially fracturing, compaction) in cores and thin sections.

For reservoir characterization and rock typing, we used an integrated approach. In this approach, the electrofacies based on petrophysical logs were determined. Then, the hydraulic flow units (HFU's) were identified firstly using a flow zone indicator. In the next step, relationships between the petrographical and petrophysical properties were evaluated for each facies based on porosity-permeability cross-plots. Finally, we established the relationships between reservoir properties of facies and HFU's (rock types).

\section{Results and Discussion}

Based on the petrographic thin sections in the Dariyan Formation, the significant facies types in the Soroush oilfield were classified as follows:

\section{1) MF1 Plagic Marls}

Description: This microfacies is characterized by its marl lithology and lamination together with pelagic fauna (particularly Globigerinid and Hedbergella). Subordinately, the silt-grade quartz and bioclast grains are present. In the core samples, the facies has greenish grey or dark color and contains pyrite minerals (as burrow fillings, framboidal or other forms). Inebioturbation and burrowing are the other characteristics of the facies, which is the faciesindeed mudstone with varying clay contents. It is recognized by relatively high readings in the GR log. The facies shows different degrees of dolomitization, and it is completely dolomitized in some parts (Figure 2(a)).

Interpretation: The occurrence of pelagic fauna (such as Globigerinids and Hedbergella), lamination and marl lithology are manifestations of deep sedimentation. Absence of benthic fossils, presence of silt-grade quartz grains and lamination, and paucity of bioturbation all denote quiet-water conditions below storm-wave base [15]-[17].

The occurrence of pyrite in dark grey marl intervals records anaerobic reducing conditions and oxygendepleted conditions. Such facies type is typical of a basinal environment and sediment starved conditions. These facies are often composed of relatively monotonous successions with few diagnostic sedimentological characteristics [15].

2) MF2 Microbioclastic Mud/Wackestone

Description: Main components of the facies (less than 20\% frequency) are microbioclastic grains, floated in micrite (biomicrite). These are mainly echinoderm debris and minorly rudist debris, uncertain bioclast debris with sponge and brachiopod spines and foraminifers (Orbitolina, Textularid, Valvulinid, Cyclaminid, Choffatella, Nodosaria). 


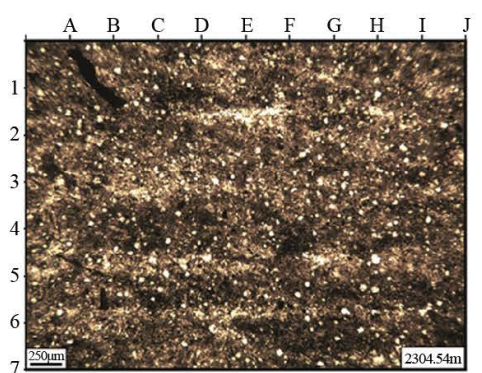

(a)

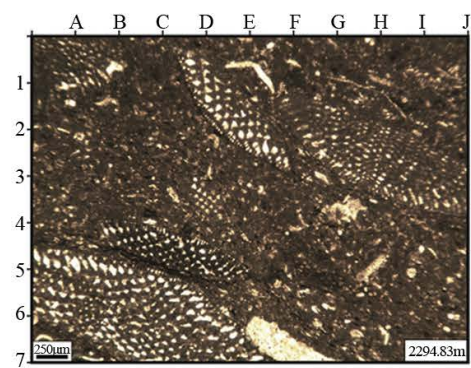

(d)

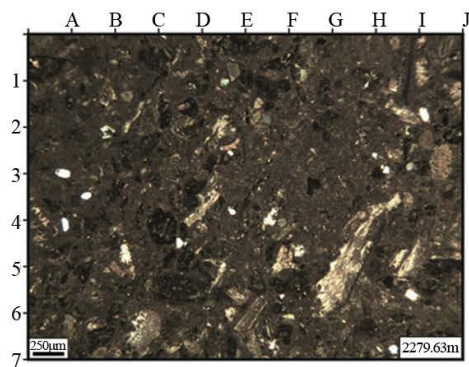

(g)

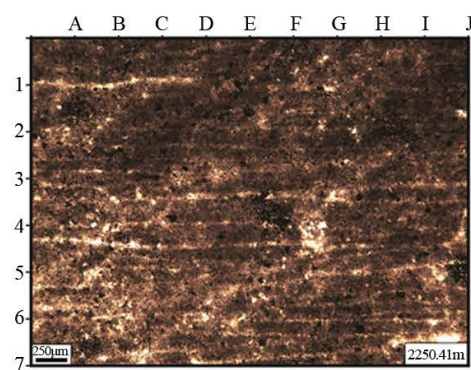

(j)



(b)

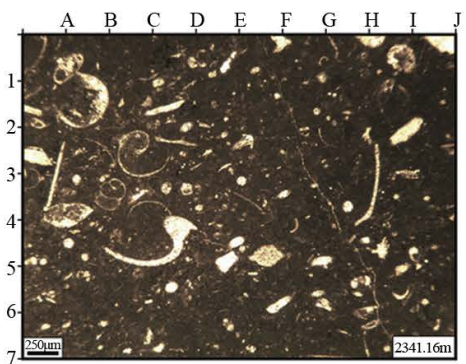

(e)

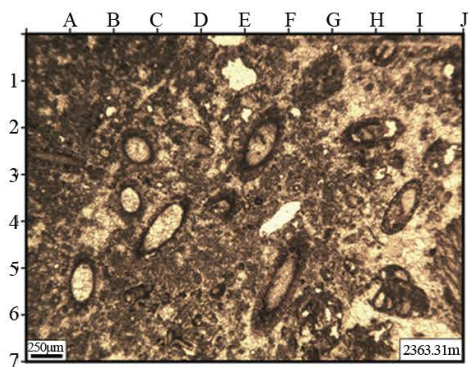

(h)

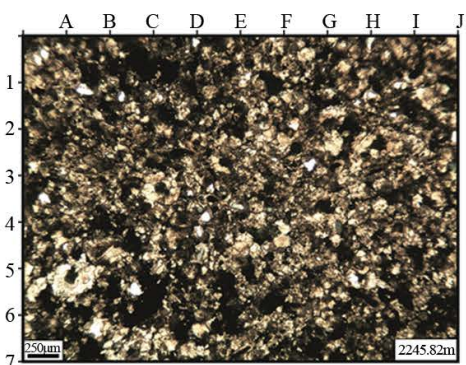

(k)

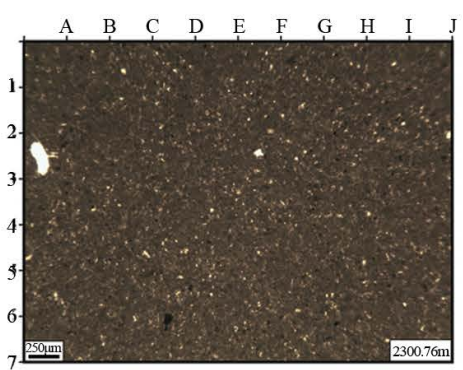

(c)

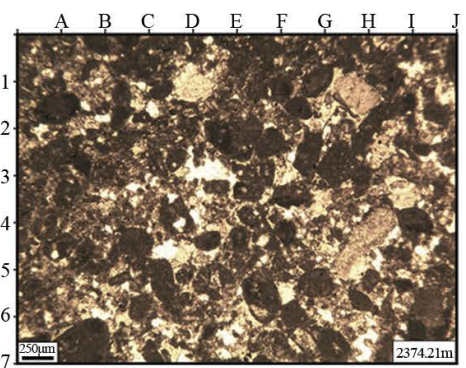

(f)

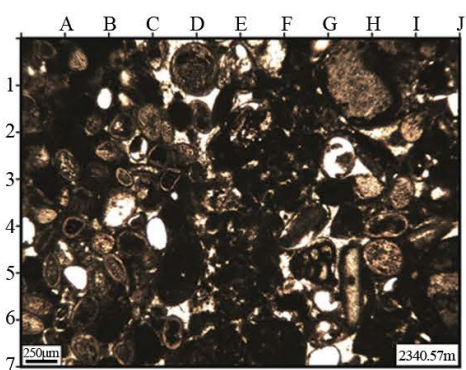

(i)

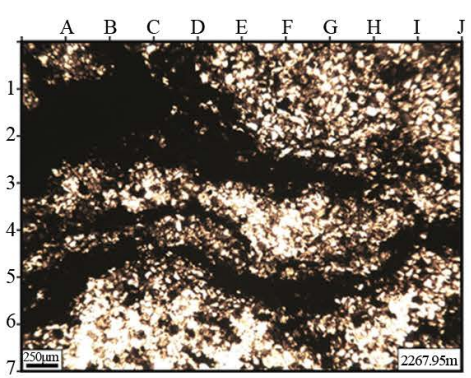

(1)

Figure 2. (a) MF1, Plagic Marls; (b) MF2, Microbioclastic Mud/Wackestone; (c) MF3, Micropeloid Wacke/Mudstone; (d) MF4, Mixed Bioclastic, orbitolina, Micropeloid wacke/packstone; (e) MF5, Sponge spicule, Echinoderm, Bioclastic Mud/Wackestone; (f) MF6, Foram, Peloid, Bioclastic Pack/Grainstone; (g) MF7, Sandy, Foram, Echinoderm Pack/Wackestone; (h) MF8, Foram-Algal Floatstone/Wackestone; (i) MF9, Bioclastic, Coated grain Wacke/ Packstone; (j) MF10, Laminated Shale/Silty Shale; (k) MF11, Ooid/Sandy Ironstone; (l) MF12, Bioturbated and wavy bedded Siltstone/Sandstone.

Micropeloids and silt-grade quartz are also seen as accessory grains. Depositional textures of the facies range from mud- to wackestone (mud-supported) or calcisiltite. It is finely bioturbated and has grey color in the cores. Lithology of the facies varies from limestone to argillaceous limestone and dolomite. Lamination and other current-related structures are not developed. Dissolution seams are the main diagenetic features in the facies. Traces of pyrite crystals are also scattered in the matrix (Figure 2(b)). 
Interpretation: The mud-dominated nature, lack of shallow water indicators, diverse open marine fauna (such as echinoderm, rudist, sponge and brachiopod spines, and Nodosaria), as well as the grain sizes (calcisiltite) all indicate a low-energy, deep open marine depositional environment [15] [16] [18]. The fine bioclasts and enrichment in echinoderm fragments point to reworking by agitated waters (storm waves). These bioclasts may have been derived from shallower mid-ramp settings. The facies is interpreted to have been deposited in outer ramp settings below the storm wave base. It may be correlated with SMF-2 and RMF-4 of Wilson (1975) and Flugel (2004).

3) MF3 Micropeloid Wacke/Mudstone

Description: Micropeloids, floated in the limy mud, are main allochems of the facies. Dispersed, minor constituents are microbioclasts (echinoderm, rudist, mollusk, and uncertain skeletal debris), foraminifers (Orbitolina, Textularid, Choffatella) and silt-grade quartz. The facies is very similar to the MF-2. Wackestone textures are prevailing, but there are also cases of local mudstone occurance (Pelmicrite texture sensu) [19]. The lithology ranges from limestone to argillaceous limestone. Fine bioturbation and massive structures are common. In the core samples, the facies has a dense nature and a grey color. Pyrite crystals and compaction features (dissolution seams) are present in the facies. Filled fractures by calcite cements are also present (Figure 2(c)).

Interpretation: Lack of current-related sedimentary structures, fine-grained nature, high mud content, and micropeloid components (or pelmicrite) prove the low energy conditions during sedimentation of the facies.

The minor presence of benthic faunal elements (predominantly echinoderm debris) and facies associations all bear testimony to the presence of open marine settings [15] [16] [18]. The facies is equivalent of Wilson's (1975) SMF 2.

The facies is believed to be deposited in an outer ramp in the deeper part of the depositional environment. This setting is characterized by significant accumulation of mud, fine-grained components, reworked open marine bioclasts and pelagic fauna.

4) MF4 Mixed Bioclastic, Orbitolina, Micropeloid Wacke/Packstone

Description: The facies is a mixture of various bioclasts (notably echinoderm, rudist, green algal, and mollusk debris) and orbitolina in a pelmicritic matrix. Foraminifers (Textularia and Choffatella) are also present as associated grains. In some cases, Orbitolina form main parts of the grains, but micropleoids occur in micritic matrix. It consists of variable textures ranging from wackestone to packstone. Bioturbation is common in the facies. Limestone is the main lithology of the facies, but minor argillaceous limestone is also present. Pyrite, glauconite, dissolution seams and cementation are the main diagenetic products and processes of the facies. Dolomitization and fractures filled by calcite are other important diagenetic processes the facies (Figure 2(d)).

Interpretation: The Orbitolina, a particular Lower Cretaceous element, flourishes in shallow tropical to subtropical waters, normal marine environments, and fore-reef areas. Its association with restricted marine biota (such as miliolids and green algae) suggests shallow water inner platform settings, whereas its assemblage with open marine fauna (like rudists and echinoderms) may indicate deeper, opener waters [20] [21]. The facies is deposited in the open marine settings with moderate energy and normal salinity [15] [16].

In addition, sedimentary criteria (texture and bioturbation) and facies association suggest that the facies is commonly deposited in a proximal mid-ramp setting and also in ramp margin environment.

5) MF5 Sponge Spicule, Echinoderm, Bioclastic Mud/Wackestone

Description: The facies is characterized by sponge spicules (clacisponges), echinoderm debris, and thin shelled bioclasts (pelagic mollusk such as bivalves and gastropods). Brachiopod spine and various foraminifers (such as Cyclaminid Textulariid, Valvulinid, Hedbergella) are subordinate constitutes. It has mud-dominated texture (mudstone and wackestone) and limestone to dolomite lithology with cream color. The facies is heavily bioturbated (mottled fabric) and trace fossils are relatively common. Lamination also occurs.

Dolomitization, dissolution seams and cementation (fracture filling and mold-filling) are notable diagenetic features in the facies. Opaque minerals (pyrite) are rarely recorded (Figure 2(e)).

Interpretation: Calcareous sponges or calcisponges live in the shallow open marine environments (10 to 100 $\mathrm{m}$ water depth) with normal salinity [22]. The mud-dominated texture with well-preserved thin-shelled mollusk suggest a low-energy and relatively deep depositional environment [16]. The co-occurrence of brachiopod debris and pelagic foraminifers support this interpretation. Accordingly, the assemblage of calcisponges, echinoderms, and pelagic mollusk with extensive bioturbation illustrates the deposition in a mid-ramp setting. Calcisponges have the ability to produce hard reefal skeletons. They also may trap lime mud sediments, forming either mud mounds or algal-spongy reefs [20]. Some patch reefs have probably flourished on the Dariyan plat- 
form.

6) MF6 Foram, Peloid, Bioclastic Pack/Grainstone

Description: The facies, with variable thickness, is mainly composed of foraminifers, peloids, and skeletal grains. Foraminifers include Orbitolina, Valvulinid, Miliolid. Peloid and uncertain grains (highly micritized bioclasts or intraclast) are present with various frequencies. Peloids can be abundant as well as bioclasts in some cases. Echinoderm, algal and rudist debris are the main bioclasts. The texture of facies is calcarenite (biosparite) or grain dominated (packstone and grainstone). Massive structure is common. Bioturbation is also present. Cross-bedding was not observed. It appears in cream and belongs to limestone lithology.

Cementation (sparry calcite), fracturing (filled by calcite cements), and compaction are the main diagenetic features of the facies. In some cases, the facies forms crashed zones of the studied formation (Figure 2(f)).

Interpretation: Considering the facies texture (dominance of bioclasts and low abundance of micrite), the facies is deposited in the high energy settings. It is probably accumulated in bioclastic shoals, as longitudinal bodies parallel to the shoreline, situated over the ramp margin [15] [16]. The shoal area is characterized by extensive marine cementation. These bodies are developed during the highstand sea level [23]. Shoal constituent grains may be derived from both back-shoal or lagoon (such as micritized grains, oncoid, and algal debris) and fore-shoal (orbitolina and echinoderm debris) settings.

Therefore, based on the particle assemblages and their origin, the facies can be divided into three sub-facies or facies zones (back, central, and fore shoal).

7) MF7 Sandy, Foram, Echinoderm Pack/Wackestone

Description: The facies is a packstone to wackestone containing echinoderm, foraminifer, and quartz sand grains. Various bioclasts (mainly echinoderm and also rudist, algal, and mollusk debris) and foraminifers (Textulariid, Orbitolina, Choffatella) are associated with the facies.

Quartz sands, as extraclasts, have more than 5\% frequency in some cases. The lithology of the facies is commonly argillaceous limestone (relatively high GR log readings). Bioturbation is common. Glauconite, pyrite, and fish debris are the accessory components. Compaction is the main diagenetic feature of the facies (Figure 2(g)).

Interpretation: According to depositional texture and fauna type, the facies is developed in the moderate energy and open marine depositional settings. The admixture of restricted (algal debris and foraminifers) and open marine (echinoderm and rudist debris) fauna with extraclast grains (quartz sands) indicate that grains of the facies are derived from various sources such as landward, lagoon, and open marine settings. Detrital minerals (e.g. terrigenous quartz) are transported from landward settings. The facies corresponds to SMF-4 of Flugel (2004) and it is deposited in the submarine channels (or re-sedimented deposits) of shallow to deep depositional settings (lagoon toward mid-ramp environments).

8) MF8 Foram-Algal Floatstone/Wackestone

Description: The most characteristic component of the facies is large Lithocodium aggregatum clasts (green algae sensu) [24], associated with various large and small foraminifers (Orbitolina, Miliolids, Valvulinid) and oncoids. Other bioclasts are ostracods, algal debris (Salpingoporella), gastropod, and echinoderms debris. The texture is mud-dominated and it shows transitions between floatstone and wackestone. The lithology ranges from limestone to dolomitic limestone, and it is cream in color. Bioturbation is also seen in slabbed core surfaces. Fracturing (filled by calcite), cementation, and dolomitization are notable diagenetic processes in the facies (Figure 2(h)).

Interpretation: The Lithocodium-rich facies (or patch reefs) are important components of certain hydrocarbon bearing carbonate reservoirs in the Middle East [25].

According to many authors [24] [26] [27], Lithocodium aggregatum is a depth indicator (representing 10 to $20 \mathrm{~m}$ ) and occurrence of this flora suggests the shallow-water settings (such as inner ramps) above fair-weather wave base. On the other hand, the micritic matrix of Lithocodium indicates low palaeocurrent velocities (less than $10 \mathrm{~cm} / \mathrm{sec}$ ), and it is more likely to have been in warm, fully marine, well oxygenated mid ramp (15 to $60 \mathrm{~m}$ ) [28]. They are developed in deep marine lagoonal environments behind rudist banks [29]. This is supported by presence of large foraminifera (such as Orbitolina and Cyclaminid), which flourish in shallow, normal marine environments and fore-reef areas [20].

The floatstone texture (large, insitu lithocodium fragments with symbiont) suggests the existence of small patch reef or algal mound on the Dariyan carbonate platform. The association of lithocodium and large foraminifers indicate deposition in the shallow, photic inner ramp (open lagoon to open marine) environments.

9) MF9 Bioclastic, Coated Grain Wacke/Packstone 
Description: The main allochems of the facies are coated grains (oncoids and peloids) and bioclasts (such as echinoderms, algae, bivalves, gastropoda, ostracoda, rudist debris, and forams). The oncoids contain large bioclastic nuclei (e.g. rounded bivalves and echinoderms) with a thick cortex (algae), and they reach up to $40 \%$ frequency in some cases. They are several millimeters in size. Foraminifers include small and large benthic forms (Textulariid, Valvulinid, Choffatella, and Miliolida). Orbitolina is very rare or absent.

Depositional textures of the facies range from wacke- to packstone. Lithologically, the facies ranges from limestone to dolomite, dolomitic limestone and argillaceous limestone. Bioturbation is common structure in the facies. Micritization, cementation, fracturing (filled by calcite), dissolution and dolomitization are characteristic diagenetic processes in the facies (Figure 2(i)).

Interpretation: The oncoids are interpreted as having been deposited in a light-penetrated and shallow-water environment. The thick cortex of oncoids and depositional textures suggest that water energy ranges from low to moderate levels. The oncoid bearing facies are common in the back-reef or shoal settings [15] [30].

Moreover, the facies textures as well as presence of peloid and oncoid indicate low to moderate depositional energy. Thus, the occurrence of a typical lagoonal skeletal fauna including green algae, miliolida, gastropoda, and benthic foraminifera and absence of open and deep marine indicative fauna suggest that the facies is formed in the lagoon environment in the inner ramp setting.

10) MF10 Laminated Shale/Silty Shale

Description: The facies is defined based on shale lithology and lamination (fissility) structure. The silty laminations and sand grains are also seen in the facies. It has a brown to grey color in the core samples. The facies is barren of fossils, but rarely could unknown bioclasts be detected. It contains relatively high amounts of organic matters. The sideritic nodules and pyrite minerals (both as burrow fillings) are common in the facies. The facies is associated with relatively high readings of GR-log (Figure 2(j)).

Interpretation: Considering the sedimentological characteristics, sedimentation of the facies occurred in low energy conditions, such as prodelta settings where sediments were deposited mostly from suspension load. Paucity of marine fauna and limited bioturbation in prodelta sediments is explained by stressful conditions with abundant suspended sediments and a mix of marine and fresh waters [31]. Presence of pyrite and glauconite and preservation of organic matters (lacking of oxidic phases and existence of dark color) in the clayey matrix suggest the reducing conditions during the deposition. Finely laminated claystones and silty claystones are typical in a prodelta environment of modern deltas [31]-[33].

11) MF11 Ooid/Sandy Ironstone

Description: The facies is ooid and quartz sand bearing ironstone (probably siderite). Quartz sands and silts (with up to 35\% frequency) are commonly scattered in the matrix. Unrecognizable bioclasts, altered during diagenesis, are rarely present. Bioturbation and burrow filling are also seen in the facies. The facies shows typically brown to cream color on the cores. Dissolution and compaction are common diagenetic features (Figure 2(k)).

Interpretation: The ooilitic ironstones are present in non-marine sandstones, mainly in deltaic systems [34][36]. These sediments are dominant in Delta fronts, particularly in warm, tropical, river-dominated deltas (Morad, 2010). Such deposits are developed in the suboxic conditions (high Fe pore waters and negligible sulfide production), where the rates of the sediment supply and accumulation are low [34]. Following the model of Dalrymple et al. (1992) [37], the facies is interpreted to have formed in an estuarine environment or proximal Prodelta.

12) MF12 Bioturbated and wavy bedded Siltstone/Sandstone

Description: The facies is greenish-grey color siltstone to sandstone containing intense bioturbation, trace fossils and a wavy bedding structure. Sands are very fine to fine in sizes. Silt to sand-grade grains are majorly quartz (Quartz wacke to Quartz arenite). It contains variable amounts of clay size materials as matrix (less than 30 percent). The facies is commonly moderate to well-sorted and has sub-angular to rounded sand grains. Textural maturity may be ranging from immature to mature. The facies is barren of fossil but horizontal burrows are recognized as common ichnofossils. Occasionally, pyrite and sideritic ooids are also present (Figure 2(I)).

Interpretation: The sandstone lithology indicates a period of sea-level lowstand as well as a strong input of quartz sands. High sand input of red-stained siliciclastics may indicate proximity to the shore line settings. Extensive horizontal bioturbation, wavy bedded, grain-rich nature, and erosional contacts point to the sedimentation in a subaqueous bar in a deltaic system [32] [35] [36].

These sediments are generally coarser than those in prodelta deposits (MF10) and suggest an increasing 
proximity to river sources [32] [33].

Due to the thin sections, the study of Soroush facies was conducted in this well (Figure 3), and the frequency of each facies in the studied well is as follows:

According to the pie chart diagrams (Figure 4), the most abundant facies is number 4, and then facies 1, 6, 9, 10, and 2, 5, 8, and 12 and finally 3 and 7 are in the next priorities respectively. Facies 11 has the lowest frequency. Consequently, in this well, 49 percent of the total frequency belongs to basin, outer ramp and mid rap, whereas 35.5 percent belongs to inner ramp (shoal and lagoon) and 15.5 percent has deltaic facies. Totally, the facies of shallow and deep areas in the studied well is almost identical.

\subsection{Sedimentary Environment}

Explaining ancient Sedimentary environments requires recognition and careful description of the facies. In this study, the models of ancient sedimentary carbonate ramp Dariyan were determined after the facies had been identified and placed in the position. To fulfil such a goal, there was also a comparison with modern environments and their relevant references [15] [16] [23] [38]-[42].

The long term regression [43] during the Aptian is recorded by shallow carbonates of the Dariyan Formation in the Zagros and Persian Gulf areas. The Dariyan carbonate platform had covered whole southwestern Iran, with the exception of central and southern Lurestan, where it is replaced by the Garau Formation [1] [44]. There were two intra-shelf basins, called Kazhdumi and Bab basins, in the Aptian carbonate platform.

The Aptian was a time of particular abundance and blooming of the Orbitolina large foraminifers (also blooming of green algae) in the carbonate platforms. Therefore, the Dariyan Formation is characterized by thick-bedded Orbitolina-rich and mud-dominated facies, which are overlain by Upper Shuaiba and Burgan clastics.

Facies analysis in the Dariyan Formation in the SR\#A indicates that this formation is mainly deposited on the deltaic system, carbonate ramp to shallow intra shelf basin settings. In addition, studies reflect facies changes that indicate the dominance of tectonic and climate controls (sea level fluctuations) during deposition of these successions. All interpretations are confirmed by results from van Buchem et al. (2010).

The Lower Dariyan carbonate ramp is dominated by photozoan carbonate producers (diverse green algae, oncoid, and symbiont-bearing larger foraminifera). Facies diversity is relatively high in this interval in comparison with the Upper Dariyan carbonates. Algal mounds and bioclastic shoals are well-developed in this platform. These facies and assemblages suggest the shallow, warm and tropical-sub tropical carbonate factory in a carbonate ramp without major terrigenous input.

In contrast, green algae have not flourished in the Upper Dariyan carbonates. Additionally, our studies show that shoal and oncoid-bearing facies are not developed in this part of formation.

The peritidal facies are not seen in the landward portion of the Upper Dariyan ramp. The poor development of light-dependent flora could result from the decrease in water transparency during clastic input. It seems that the landward section of the Upper Dariyan ramp is strongly influenced by siliciclastics input, triggered by the falling sea level. These clastics were mainly derived from the west, in Arabian Shield [45]. Increasing terrigenous input may have been related to a change in humid climatic conditions (high rainfall) in the hinterland. In the middle part of the Dariyan Formation, the shallow lagoonal and shoal facies with meteoric diagenetic signatures are immediately replaced by pelagic marls (Kazhdumi Tongue). This rapid deepening trend has been interpreted as a result of sedimentation in the intrashelf basin. The low frequency and diversity of pelagic fauna in these marls suggest that the basin has not very deep basinal conditions (approximately $135 \mathrm{~m}$ ) [44]. The basin, Kazhdumi intrashelf, was formed by activation of Kazerun and Hendijan faults in the Aptian [44]. Table 1 and Figure 5 depict the locations specified in the well under study and the microfacies in Soroush oilfield within different sedimentary environments.

\subsection{Determination Electrofacies}

With respect to the fact that, the main purpose of determining the facies is determination of reservoir units, the reservoir logs will be inserted in the system. Accordingly, reservoir logs are noticed and gamma ray log plays an important role in investigation of shale effects.

Then, GR, PHIE and SWE will be selected as entered logs to Geolog and after that the following logs will be traced (Figure 6). 


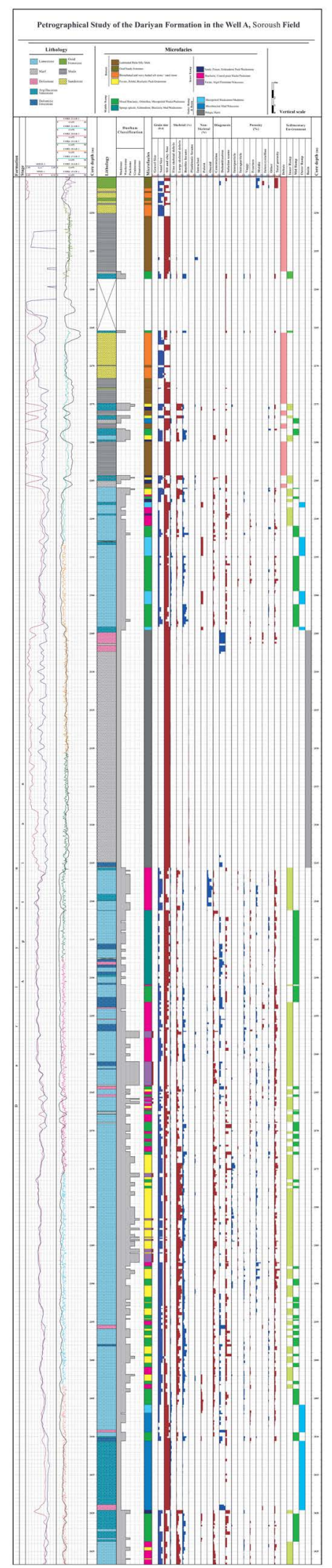

Figure 3. Facies log in well A. 


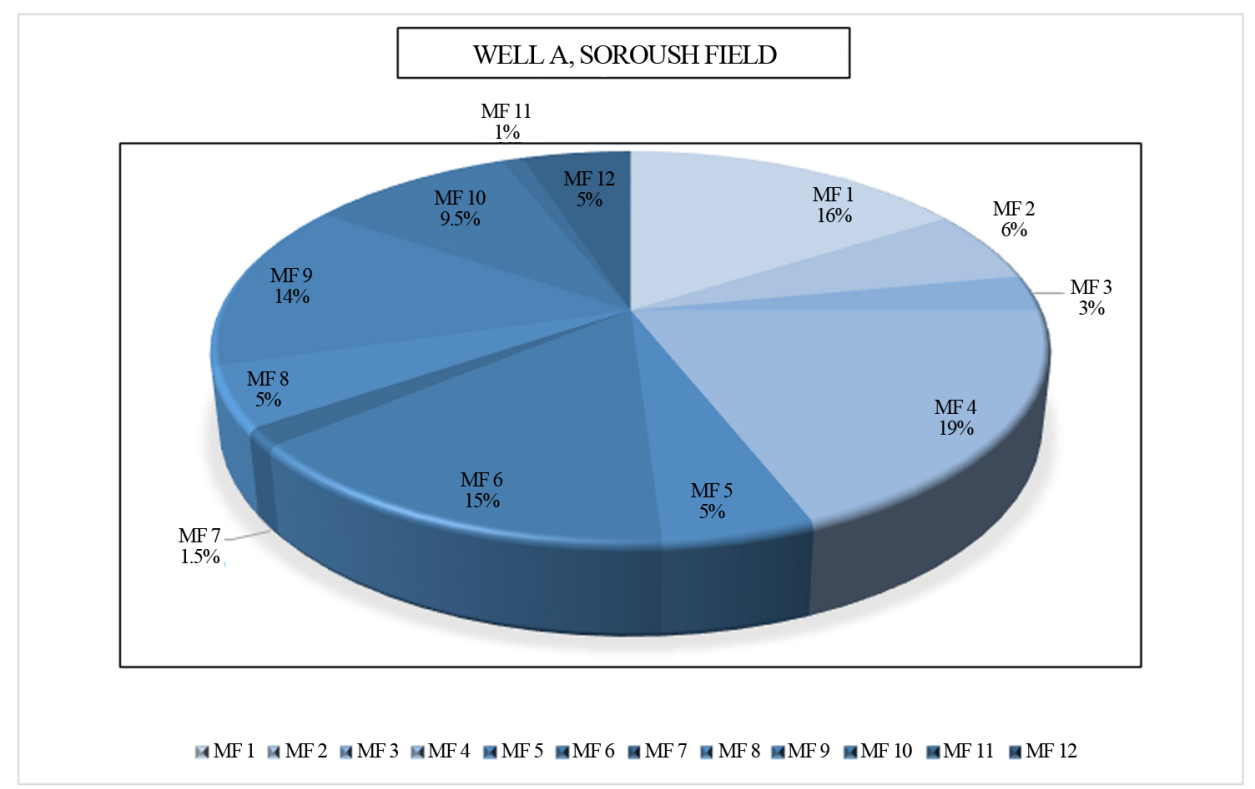

Figure 4. Facies frequency defined in the studied well in Soroush oilfield.

(a) Upper Dariyan Clastic-Carbonate (Mixed Clastic-Carbonate Ramp)

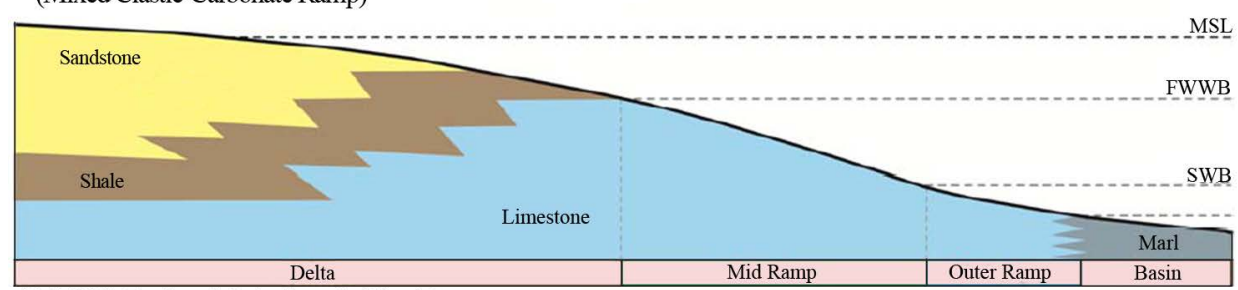

(b) Middle Dariyan Marls (Intrashelf basin)

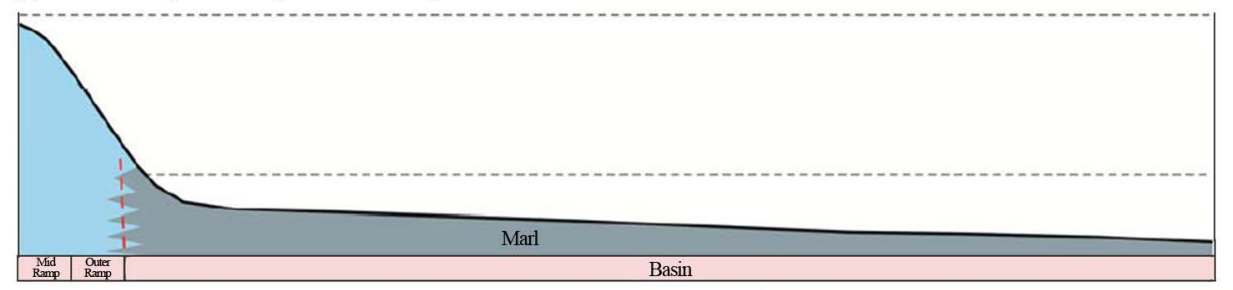

(c) Lower Dariyan Carbonate (Carbonate Ramp)



Figure 5. Dariyan Formation's sedimentary environments of Soroush oilfield.

After data training, in order to identification of electrofacies, MRGC method was applied in Facimage (Geo$\log$ ) and KNN algorithm was used to do cluster analysis and define electrofacies (Figure 7).

Regarding the electrical facies determination and diagrams on the Soroush field (Figure 8), it was observed that in the electrofacies, which are demonstrated with dark blue color, shale volume was very high and poor in reservoir quality. The shale volume of the green electrofacies was very high mainly and porosity was low and poor in reservoir quality. Yellowish green electrofacies is mainly composed of calcite with low shale volume 


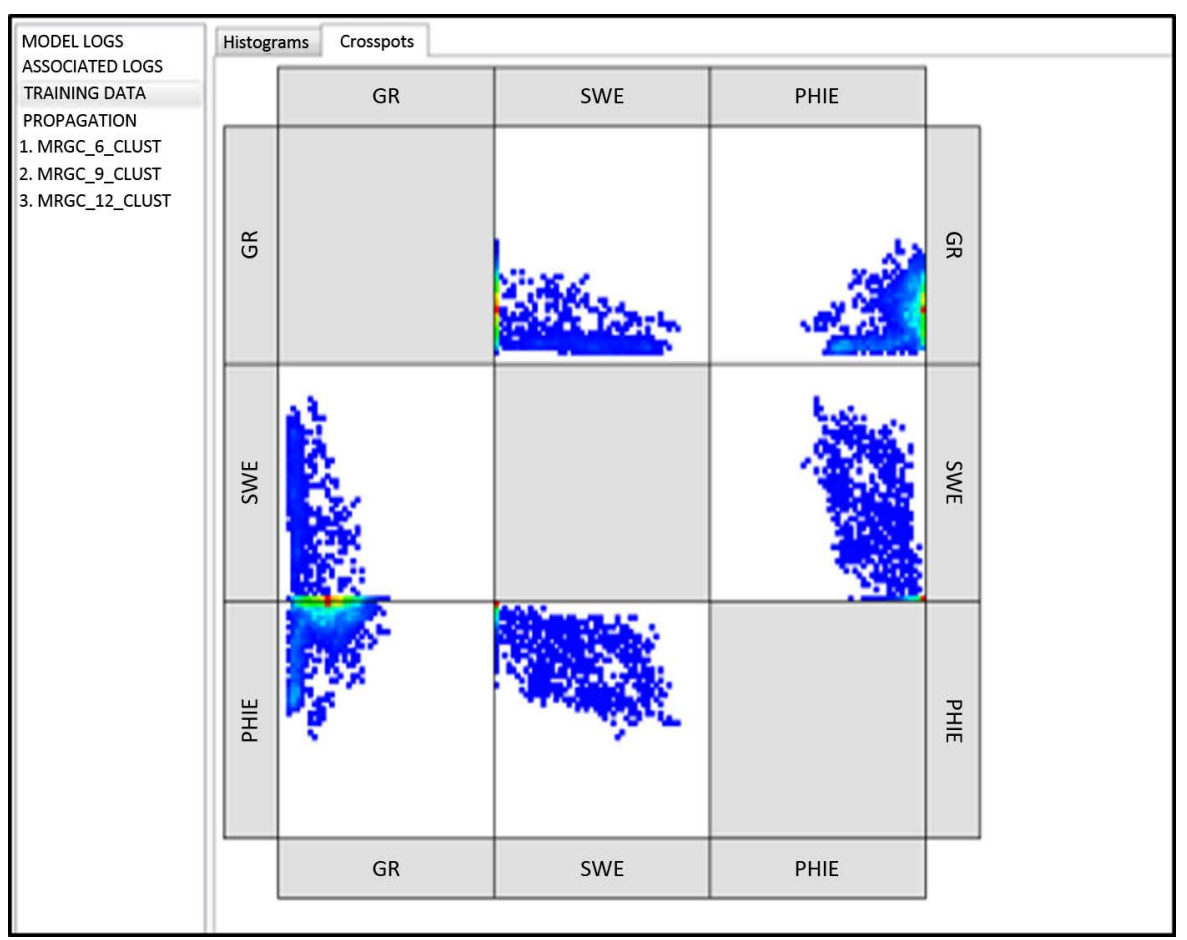

Figure 6. Amounts of frequency determination used to define rock types of Dariyan Formation in Soroush oilfield.

Table 1. Location of specified Dariyan Formation microfacies in different sedimentary environments, Soroush oilfield.

\begin{tabular}{cccc}
\hline Lithology & Code & facies name & Environment \\
& MF1 & Plagic Marl & Basin \\
& MF2 & Microbioclastic Mud/Wackestone & Outer Ramp \\
& MF3 & Micropeloid Wacke/Mudstone & Middle Ramp \\
MF4 & Mixed Bioclastic, orbitolina, Micropeloid wacke/packstone & Inner Ramp (Shoal) \\
MF5 & Sponge spicule, Echinoderm, Bioclastic Mud/Wackestone & Inner Ramp (Lagoon) \\
& MF6 & Foram, Peloid, Bioclastic Pack/Grainstone & Delta \\
\hline
\end{tabular}

and so poor porosity in reservoir quality. Yellow electrofacies mainly has calcitic with low shale volume and moderate porosity; it has average reservoir quality as well. Red electrofacies is mainly calcitic with a poor shale volume; porosity is high and within the other facieses has the highest volume reservoir quality.

Consequently, from the reservoir qulality point of view, it is possible to classify the determined electrofacies to 3 classes:

-Poor in reservoir quality (facies in dark blue, green andyellowish green).

-Moderate reservoir quality (facies in yellow).

-Good reservoir quality (facies in red). 


\begin{tabular}{|l|l|r|r|r|r|r|r|}
\cline { 2 - 7 } \multicolumn{1}{c|}{ NAME } & COL & PAT & WEIGHT & GR & SWE & PHIE \\
\hline 1 & FACIES_1 & & & 975 & & \\
\hline 2 & FACIES_2 & & & 1346 & \\
\hline 3 & FACIES_3 & FACIES_4 & & & 549 & & \\
\hline 5 & FACIES_5 & & & 351 & & \\
\hline
\end{tabular}

Figure 7. On the basis of petrophysical logs, 5 rock types are determined by neural network method for well\#A in Soroush oilfield.

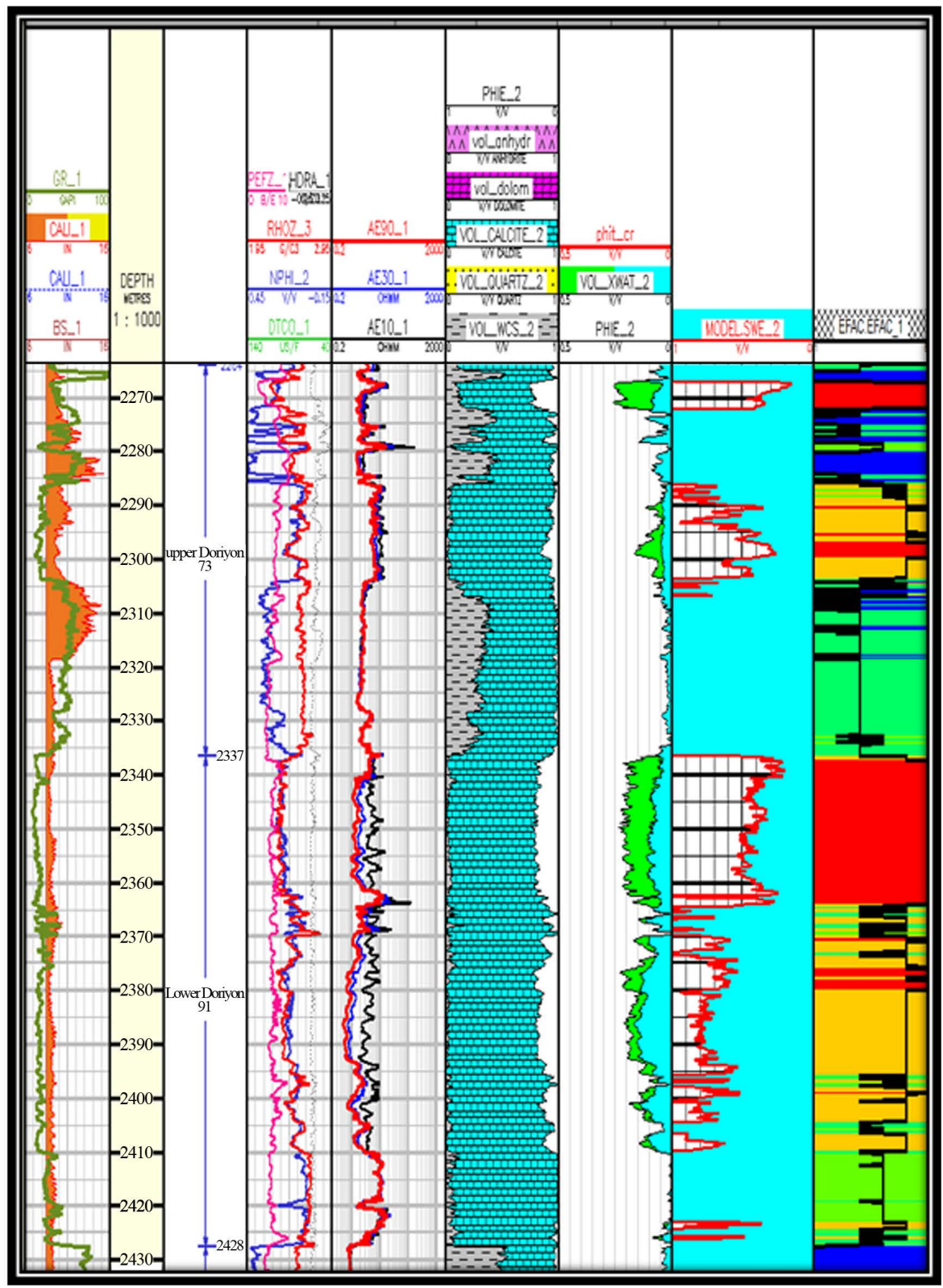

Figure 8. Illustration of rock type distribution in petrophysical interpretation as electrofacies in Dariyan Formation, well\#A, Soroush oilfield. 


\subsection{Comparison of Microfacies and Electrofacies}

Electrofacies with dark blue, green, and yellowish green colors, which are poor in reservoir quality, are matched with microfacies 1, 2, 3, 7, 10 and 11. Electrofacies in yellow, which has a moderate reservoir quality, is correlated with microfacies 4 and 6 . The red lectrofacies, which has the highest reservoir quality, is correlated with microfacies 5, 8, 9 and 12 (Figure 9).
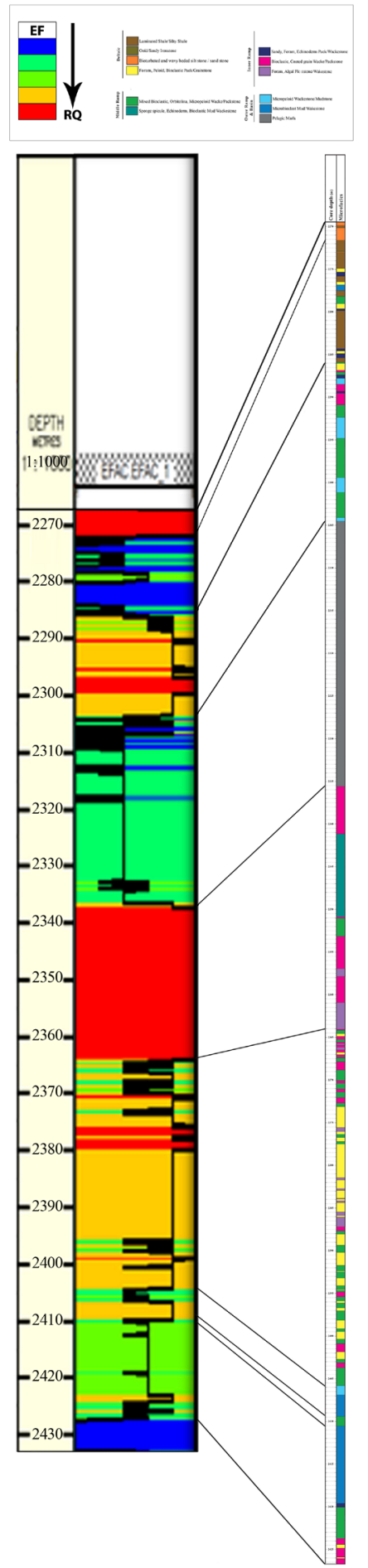

Figure 9. Correlation of microfacies and electrofacies. 
The comparision between microfacies and electrofacies that were identified in the studied well indicated that in Soroush field facies of deep basin areas (outer ramp and open marine) are mainly poor in reservoir quality. Middle ramp facies, divided into two species of rich facies Orbitolina, have average reservoir quality, while Sponge facies have high reservoir quality. Shoal facies have average reservoir quality, while inner ramp facies (Lagoon) that were divided into two species of sandy calcitic facies are poor in reservoir quality. In contrast, other lagoon facies have high reservoir quality, and mainly the clastic facies for deltaic region, except bioturbated sandstone, are poor in reservoir quality.

\subsubsection{Reservoir Characterization and Rock Typing}

Reservoir rock characterization, classification, and ranking are essential steps in reservoir studies. Identification of major rock types of the reservoirs is the main objective of this analysis. Rock types have similar depositional and diagenetic history with unique reservoir properties and are building blocks of geological models. Here, we used an integrated approach for characterization and rock typing of the Dariyan Formation. In this approach, firstly hydraulic flow units (HFU) were identified using a flow zone indicator [46]-[49].

In second step, the relationships between petrographical and petrophysical properties for each facies were evaluated based on porosity-permeability crossplots.

Finally, we established the relationships between reservoir properties of facies and HFU's (rock types). Based on these studies, all samples of SCAL and NMR were selected. This method is detailed below and the results were analyzed and then compared.

\subsubsection{Hydraulic Flow Unit (HFU) Determination Using a Flow Zone Indicator (FZI)}

A flow unit is defined as a volume of rock in which the pore-throat properties of the porous medium, which govern the hydraulic character of the rock, are both consistently predictable and significantly different from those of other units [47]-[52]. A reservoir may be divided into flow units to describe its performance when it is subject to different production schemes, and the subdivision can be made from either geological or engineering standpoints. However, in order to understand and model the spatial distribution of reservoir characteristics, 1D engineering data should be integrated with 3D geological data [52].

Discretizing the reservoir into units, such as layers and blocks, and assigning values of all pertinent physical properties to these units will improve understanding of the reservoir's heterogeneity. The Hydraulic Unit concept [50] can be used to divide a reservoir into distinct petrophysical types, each with a unique Flow Zone Indicator (FZI) value [53].

Kozeny (1927) and Carmen (1937) [54] [55] simulated a porous medium as a bundle of capillary tubes that combine Darcy's law for flow in a porous medium and Poiseuille's law for flow in a tube. In order to describe the relationships between porosity and permeability, a tortuosity factor was included because in reality connected pores are not straight capillary tubes.

Kozeny is one of the most fundamental and famous equations which defines permeability as a function of porosity and specific area, the extended equation Kozeny-Carmen is as below:

$$
K=\frac{\varphi^{3}}{(1-\varphi)^{2}}\left[\frac{1}{F_{S} \tau^{2} s_{v g r}^{2}}\right]
$$

If permeability is in terms of millidarcy, the following parameter can be introduced:

$$
\operatorname{RQI}(\mu \mathrm{m})=\% 314 \sqrt{\frac{K}{\varphi}}
$$

In which RQI is the index quality of the reservoir,

Qz as is defined as the portion of the pore volume to the grain volume:

$$
\varphi_{Z}=\left(\frac{\varphi}{1-\varphi}\right)
$$

FZI is considered as a flow zone indicator: 


$$
\operatorname{FZI}(\mu \mathrm{m})=\frac{1}{\sqrt{F_{S} \tau S_{v g r}}}
$$

With the logarithm of both sides we have:

$$
\log \mathrm{RQI}=\log \varphi+\log \mathrm{FZI}
$$

Therefore, for the samples with the same FZI, charting log RQI against Qz will be a straight line with a slope of the unit. The flow zone indicator value can intercept the line in $\mathrm{Qz}=1$ achieved. Samples by different values of flow zone indicator make other parallel lines. All the samples are located on a line with the same pore throat, which constitute a single flow unit.

\subsection{Rock Typing in the Dariyan Formation}

Based on the FZI method, we defined four HFU's or rock types in the Dariyan Formation of Soroush Field (SR\#A). Table 2 gives the various HFU's, FZI values, and mean poroperm values of all rock types. These rock types ranked in various reservoir qualities (from poor to good). Aporosity/permeability cross-plot of various rock types is presented in Figure 10.

To elaborate on relationships between facies types and reservoir quality, we correlated facies and core poroperm data. Arithmetic and geometric means of porosity and permeability are calculated for each facies and presented in Table 3.

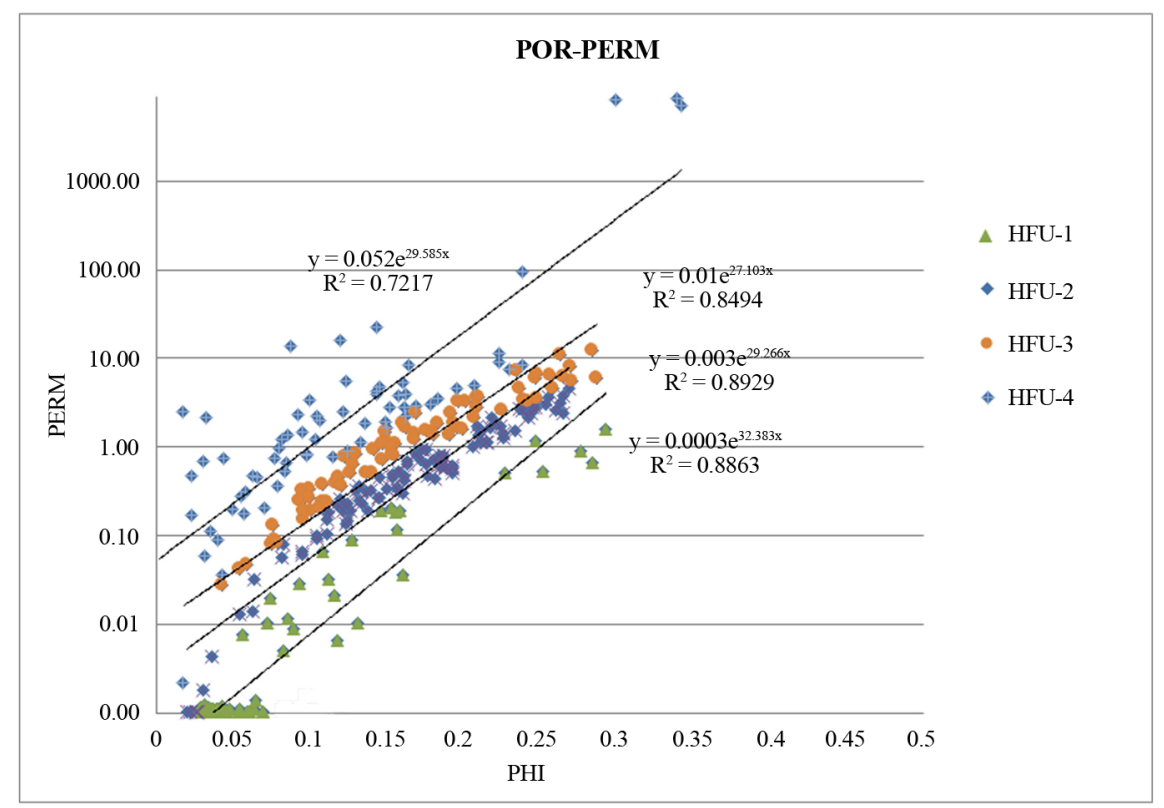

Figure 10. Porosity/permeability cross-plotof determined rock type in Dariyan Formation Soroush Oilfield.

Table 2. Petrophysicalproperties of determined rock type in Dariyan Formation Soroush Oilfield.

\begin{tabular}{ccccccc}
\hline \multirow{2}{*}{ HFU } & Log FZI & \multicolumn{2}{c}{ Arithmetic } & \multicolumn{2}{c}{ Geometric } & Reservoir \\
\cline { 3 - 6 } & & Porosity (\%) & Permeability (md) & Porosity (\%) & Permeability (md) & quality \\
\hline HFU1 & $<(-1)$ & 7.00 & 0.005 & 7.15 & 0.001 & 0.045 \\
HFU2 & $(-1)$ to $(-0.5)$ & 12.20 & 0.48 & 10.24 & 0.92 & Foir \\
HFU3 & $(-0.5)$ to 0 & 16.00 & 2.11 & 14.25 & 1.05 & Medium \\
HFU4 & $>0$ & 7.80 & 6.00 & 6.75 & & Good \\
\hline
\end{tabular}


Table 3. Statistical parameters of different microfacies of the Dariyan Formation in the Soroush Field, according to the porosity and permeability values.

\begin{tabular}{|c|c|c|c|c|c|c|}
\hline \multirow{2}{*}{ Facies } & \multirow{2}{*}{ Depositional environment } & \multicolumn{2}{|c|}{ Arithmetic } & \multicolumn{2}{|c|}{ Geometric } & \multirow{2}{*}{$\begin{array}{c}\text { Oil } \\
\text { staining }\end{array}$} \\
\hline & & $\Phi(\%)$ & $\mathrm{K}$ (md) & $\Phi(\%)$ & $\mathrm{K}(\mathrm{md})$ & \\
\hline MF-1 & Basin & 5.27 & 0.12 & 5.13 & 0.01 & - \\
\hline MF-2 & Outer Ramp & 7.52 & 0.011 & 7.26 & 0.002 & - \\
\hline MF-3 & Outer Ramp & 6.71 & 0.10 & 5.98 & 0.01 & - \\
\hline MF-4 & Middle Ramp & 10.51 & 1.09 & 9.025 & 0.07 & + \\
\hline MF-5 & Middle Ramp & 22.77 & 2.66 & 22.41 & 1.93 & + \\
\hline MF-6 & Inner Ramp (Shoal) & 13.40 & 1.13 & 11.66 & 0.36 & + \\
\hline MF-7 & Inner Ramp (Lagoon) & 3.382 & 0.120 & 3.136 & 0.005 & - \\
\hline MF-8 & Inner Ramp (Lagoon) & 16.81 & 2.68 & 16.38 & 1.42 & + \\
\hline MF-9 & Inner Ramp (Lagoon) & 15.81 & 1.93 & 14.6 & 0.85 & + \\
\hline MF-10 & Offshore delta & 13.88 & 1.38 & 12.37 & 1.76 & - \\
\hline MF-11 & Offshore delta & 12.35 & 1.63 & 7.46 & 0.53 & - \\
\hline MF-12 & Delta & 24.32 & 14.25 & 23.27 & 1.59 & + \\
\hline
\end{tabular}

The main results from the correlation of facies types and their poroperm values can be summarized as follows.

a) Porosity ranges from nil to approximately $30 \%$ and permeability varies from zero to $10 \mathrm{mD}$ or all facies.

b) Some facies have good reservoir properties and it seems that they are not important as reservoir rocks. As well, they do not show oil staining in core samples. These are MF-1, MF-2, MF-3, MF-7 and MF-10.

c) The Orbitolina-rich facies (MF-4 and) show moderate porosity, low to moderate permeability, and moderate oil staining.

d) The MF-5 (Sponge spicule bearing facies) abnormally shows high porosity and moderate permeability (1-10 mD). There is not a significant level of visible porosity in the thin sections of the facies. It seems that micro-porosity is important pore type in the facies.

e) Exept for MF-6, MF-8 and MF-9 display relatively moderate to good reservoir properties.

f) Sandstone facies (MF-11 and MF-12) and ironstones indicate moderate to good reservoir properties but only MF-12 contains good oil staining.

\subsection{Tectonic Setting}

Dominant structural trend in Persian Gulf foreland basin province is NW-SE, but Soroush oilfield has got east-west trend. Based on previous work on the neotectonic regime in Iran [56], Zagros in south Iran is the most active zone [57]-[59]. Then, Alborz [60]-[62] and Central Iran [63] [64] have been situated in the next orders. From neotectonics point of view, Persian Gulf is a peripheral foreland basin that formed on the northeastern part of Arabian plate's passive margin. Persian Gulf has continued to end of Mesopotamian area in central Iraq and have named Persian Gulf-Mesopotamian foreland basin. Persian Gulf-Mesopotamian foreland basin is north margin of internal platform of north margin of Arabian craton [65]. Therefore, trend of Soroush oilfield has been followed from the old extensional E-W Tethyan Trend [66]. It is one of the major basement fault trends that controls salt tectonism in the Persian Gulf basin.

\section{Conclusions}

1) Using petrographic studies of the Dariyan Formation in Soroush oilfield, 12 microfacies have been identified: Pelagic Marls, Micro bioclastic Mud/Wackestone, Micro peloid Wacke/Mudstone, Mixed Bioclastic, orbitolina, Micropeloid wacke/packstone, Sponge spicule, Echinoderm, Bioclastic Mud/wackestone, Foram, Peloid, Bioclastic pack /Grainstone, Sandy, Foram, Echinoderm pack/wackestone, Foram, Algal Floatstone/Wackestone, 
Bioclastic, Coated grain wacke/Packstone, Laminated shale/silty shale, Ooid/sandy Iron stone, Bioturbated and wavy bedded silt stone/sand stone.

2) According to the pie chart diagrams 49 percent of frequency belongs to basin, outer ramp, and mid ramp facies, whereas 35.5 percent belongs to inner ramp (shoal and lagoon), and 15.5 percent belongs to deltaic facies. In total, the facies of shallow and deep parts of basins are virtually identical.

3) The static model of the field indicates that there was a carbonate ramp with well-developed shoal and algal mound facies during deposition of lower carbonates. This depositional setting is modified to intra shelf basin by tectonic activities causing the deposition of the middle marls (Kazhdumi tongue). Sea level fall in humid climate made a carbonate ramp with marginal deltaic system extend during deposition of upper carbonates and clastics of the Dariyan Formation. Overall, our studies indicate that depositional setting of the Dariyan Formation was strongly affected by climate and tectonic activity.

4) 5 electrofacies by neural network method and based on the Flow Zone Indicator (FZI) method, four Hydraulic Flow Units (HFU) or rock types were defined in the Dariyan Formation.

5) Correlation between microfacies and rock types reveals that all inner ramp facies (shoal and lagoon facies) display relatively moderate to good reservoir properties except sandy calcitic facies. And bioturbated sandstone of the upper Dariyan has high reservoir quality.

\section{Acknowledgements}

The authors would like to acknowledge, with deep appreciation and gratitude, invaluable help of the staff of Research \& Development Department and experts of Iranian Offshore Oil Company for providing us with guidance, required data, and all facilities.

\section{References}

[1] James, G.A. and Wynd, J.G. (1965) Stratigraphic Nomenclature of Iranian Oil Consortium Agreement Area. American Association of Petroleum Geologists Bulletin, 49, 2182-2245.

[2] Frost, S.H., Bliefnick, D.M. and Harris, P.M. (1983) Depositional and Porosity Evolution of a Lower Cretaceous Rudist Buildup, Shuaiba Formation of Eastern Arabian Peninsula. In: Harris, P.M., Ed., Carbonate Buildups: Society of Economic Paleontologyists and Mineralogists, Core Workshop No. 4, 381-410. http://dx.doi.org/10.2110/cor.83.01.0381

[3] Harris, P.M., Frost, S.H., Seiglie, G.A. and Schneidermann, N. (1984) Regional Unconformity and Depositional Cycles, Cretaceous of the Arabian Peninsula. In: Sdnlee, J.S., Ed., Interregional Unconformities and Hydrocarbon Accumulation, American Association of Petroleum Geologist, Memoir 36, 67-80.

[4] Ghazban, F. (2009) Petroleum Geology of the Persian Gulf. Tehran University Press, Tehran, 707 p.

[5] Shemirani, A., Seyedemami, K., Amirbakhtiyar, H. and Ghalavand, H. (2000) Conducted a Lithostratigraphic and Biostratigraphic Study on Dariyan and Kazhdumi Formations in the South West of Iran. Proceedings of the Fourth Symposium of the Geological Society of Iran, Tabriz, 29-31 August 2000.

[6] Rahimpourbonab, H., Moradi, M., Naseri, Z. and Rezaee, M. (2002) Studied the Reservoir's Characteristics and Sedimentary Environment of Dariyan Formation in Persian Gulf (Persian Gulf from the Strait of Hormuz to Extreme Northwest). Tehran University, Tehran.

[7] Lasemi, Y. and Siyahi, M. (2005) Sequence Stratigraphy and Sedimentary Environment of Dariyan Formations in Southern Part of Dezful Embayment (Khami Section and Well Sulabadar 3). Proceedings of the Ninth Conference of the Geological Society of Iran, Tehran, 30-31 August 2005, 566-570.

[8] Poorbagher, M., Muosaviharami, R., Mahboobi, A., Najafi, M. and Rahmani, A. (2006) Compared the Anticline Aneh and Well Chelingar 3 in Dariyan Formation Microfacies. Proceedings of the Twenty-Fifth Meeting of Earth Sciences, Tehran, 19-21 February 2006.

[9] Adabi, M. and Abbasi, R. (2009) Analyzed the Diagenetic History of Black Mountain in North East of Shiraz and Well Sabzpooshan 1 Based on Petrographic and Geochemical Characteristics of Dariyan Formation. Tehran University Science Journal.

[10] Amiri, M., Rahimpourbonab, H., Asadi, A. and Sarafi, M. (2009) Studied Sedimentary Environments and Sequence Stratigraphy of Dariyan Formation in South Pars Oilfield. Sedimentology and Stratigeraphy Research Journal.

[11] Saadirad, F., Muosaviharami, R., Mahboobi, A., Mahmoodigharaee, M. and Armoon, A. (2010) Investigated Syndepositional History and Post Depositional of Dariyan Formation in Azadegan Oilfield. Proceedings of the Twenty-Ninth Meeting of Earth Sciences, Tehran, 15-16 February 2010. 
[12] Alsharhan, A.S. and Nairn, A.E.M. (1997) Sedimemtary Basins and Petroleum Geology of the Middle East. Elsevier, Amsterdam, $942 \mathrm{p}$.

[13] Alsharhan, A.S. (1985) Depositional Environments, Reservoir Units Evolution and Hydrocarbon Habitat of Shaiba Formation, Lower Cretaceous, Abu Dhabi, United Arab Emirates. The American Association of Petroleum Geologists Bulletin, 69, 899-912.

[14] Dunham, R.J. (1962) Classification of Carbonate Rocks According to Depositional Texture. In: Ham, W.E., Ed., Classification of Carbonate Rocks, American Association of Petroleum Geologists Memoir 1, 108-121.

[15] Wilson, B.R. (1975) Carbonate Facies in Geological History. Springer, Berlin, 471. http://dx.doi.org/10.1007/978-1-4612-6383-8

[16] Flugel, E. (2004) Microfacies of Carbonate Rocks. Springer, Berlin, 976 p. http://dx.doi.org/10.1007/978-3-662-08726-8

[17] Ruf, M., Link. E., Pross, J. and Aigner, T. (2005) Integrated Sequence Stratigraphy: Facies, Stable Isotope and Palynofacies Analysis in a Deeper Epicontinental Carbonate Ramp (Late Jurassic, SW Germany). Sedimentary Geology, 175, 391-414. http://dx.doi.org/10.1016/j.sedgeo.2004.12.023

[18] Van Buchem, F., Gaumet, F., Védrenne, V. and Vincent, B. (2006) Middle East Cretaceous Sequence Stratigraphy Study. Unpublished Report, NIOC-IFP, 167 p.

[19] Folk, R.L. (1959) Practical Petrographic Classification of Limestones. The American Association of Petroleum Geologists Bulletin, 43, 1-38.

[20] Sadooni, F.N. (1993) Stratigraphic Sequence, Microfacies, and Petroleum Prospects of the Yamama Formation, Lower Cretaceous, Southern Iraq. AAPG Bulletin, 77, 1971-1986.

[21] Sadooni F.N. and Alsharhan, A.S. (2003) Stratigraphy, Microfacies, and Petroleum Potential of the Mauddud Formation (Albian-Cenomanian) in the Arabian Gulf basin. AAPG Bulletin, 87, 1653-1680. http://dx.doi.org/10.1306/04220301111

[22] Flugel, E. (1982) Microfacies Analyses of Limestone Rocks. Springer, Berlin, 631. http://dx.doi.org/10.1007/978-3-642-68423-4

[23] Burchette, T.P. and Wright, V.P. (1992) Carbonate Ramp Depositional System. Sedimentary Geology, 79, 3-57. http://dx.doi.org/10.1016/0037-0738(92)90003-A

[24] Schlagintweit, F. and Bover-Arnal, T. (2012) The Morphological Adaption of Lithocodium aggregatum ELLIOTT (Calcareous Green Alga) to Cryptic Microhabitats (Lower Aptian, Spain): An Example of Phenotypic Plasticity. Facies, 58, 37-55. http://dx.doi.org/10.1007/s10347-011-0272-2

[25] Alsharhan, A.S. and Nairn, A.E.M. (1993) Carbonate Platform Models of Arabian Cretaceous Reservoir. In: Simo, J.A.T., Scott, R.W. and Masse, J.P., Eds., Cretaceous Carbonate Platforms, American Association of Petroleum Geologists Memoir 56, 173-184.

[26] Tucker, M.E. and Wright, V.P. (1990) Carbonate Sedimentology. Blackwell Scientific Publications, Oxford, 482. http://dx.doi.org/10.1002/9781444314175

[27] Leinfelder, R.R. (2001) Jurassic Reef Ecosystems. In: Stanley Jr., G.D., Ed., The History and Sedimentology of Ancient Reef Systems, Kluwer, New York, 251-309. http://dx.doi.org/10.1007/978-1-4615-1219-6 8

[28] Banner, F.T. and Simmons, M.D. (1994) Calcareous Algae and Foraminifera as Water-Depth Indicators: An Example from the Early Cretaceous Carbonates of Northeast Arabia. In: Simmons, M.D., Ed., Micropalaentology and Hydrocarbon Exploration in the Middle East, Chapman \& Hall, London, 243-252.

[29] Hughes, G.W. (2000) Bioecostratigraphy of the Shu'aiba Formation, Shaybah Field, Saudi Arabia. GeoArabia, 5, 545578.

[30] Scholle, P.A., Bebout, D.G. and Moore, C.H. (1983) Carbonate Depositional Environments. AAPG Memoir, 33, 297343.

[31] Bhattacharya, J.P. (2003) Deltas and Estuaries. In: Middleton, G.V., Ed., Encyclopedia of Sedimentology, Kluwer Academic, Dordrecht, 145-152. http://dx.doi.org/10.1007/978-1-4020-3609-5_62

[32] Coleman, J.M. and Prior, D.B. (1980) Deltaic Sand Bodies. Short Course Education Course Note Series, AAPG, 5.

[33] Ito, M., O’Connell, S., Stefani, A. and Borella, P. (1992) Fluviodeltaic Succession at the Wombat Plateau: Upper Triassic Siliciclastic-Carbonate Cycles. Proceedings of the Ocean Drilling Program, Scientific Results, 122, 109-128. http://dx.doi.org/10.2973/odp.proc.sr.122.139.1992

[34] Taylor, K.G., Simo, J.A., Yocum, D. and Leckie, D.A. (2002) Stratigraphic Significance of Ooidal Ironstones from the Cretaceous Western Interior Seaway: The Peace River Formation, Alberta, Canada, and the Castlegate Sandstone, Utah, USA. Journal of Sedimentary Research, 72, 316-327. http://dx.doi.org/10.1306/060801720316 
[35] Buatois, L.A., Santiago, N., Parra, K. and Steel, R. (2008) Animal-Substrate Interactions in an Early Miocene WaveDominated Tropical Delta: Delineating Environmental Stresses and Depositional Dynamics (Tacata Field, Eastern Venezuela). Sedimentary Geology, 78, 458-479. http://dx.doi.org/10.2110/jsr.2008.053

[36] Morad, S., Al-Ramadan, K., Ketzer, J.M. and De Ros, L.F. (2010) The Impact of Diagenesis on the Heterogeneity of Sandstone Reservoirs: A Review of the Role of Depositional Facies and Sequence Stratigraphy. AAPG Bulletin, 94, 1267-1309. http://dx.doi.org/10.1306/04211009178

[37] Dalrymple, R.W., Zaitlin, B.A. and Boyd, R. (1992) Estuarine Facies Models: Conceptual Basis and Stratigraphic Implications. Journal of Sedimentary Petrology, 62, 1130-1146. http://dx.doi.org/10.1306/D4267A69-2B26-11D7-8648000102C1865D

[38] Read, J.F. (1985) Carbonate Platform Facies Models. AAPG Bulletin, 69, 1-21.

[39] Shinn, E.A. (1986) Carbonate Depositional Environments Modern and Ancient-Part 1: Tidal Flats. Colorado School of Mines Quarterly, 81, 1-74.

[40] Reading, H.G. (1996) Sedimentary Environments: Processes, Facies and Stratigraphy. 3rd Edition, Blackwell Science, Oxford, 669.

[41] Tucker, M.E. (2001) Sedimentary Petrology. Blackwell Scientific Publications, Oxford, 260 p.

[42] Warren, J.K. (2006) Evaporites: Sediments, Resources and Hydrocarbons. Springer, Berlin, 1036 p. http://dx.doi.org/10.1007/3-540-32344-9

[43] Haq, B.U., Hardenbol, J. and Vail, P.V. (1988) Mesozoic and Cenozoic Chronostratigraphy and Cycles of Sea-Level Change. In: Wilgus, C.K., Hastings, B.S., Kendall, C.G.St.C., Posamentier, H.W., Ross, C.A. and Van Wagoner, J.C., Eds., Sea-Level Changes: An Integrated Approach, Volume 42, SEPM Special Publication, 71-108. http://dx.doi.org/10.2110/pec.88.01.0071

[44] Van Buchem, F.S.P., Baghbani, D., Bulot, L.G., Caron, M., Gaumet, F., Hosseini, S.A., Keyvani, F., Schroeder, R., Swennen, R., Vedrenne V. and Vincent, B. (2010) Barremian-Lower Albian Sequence-Stratigraphy of Southwest Iran (Gadvan, Dariyan and Kazhdumi Formations) and Its Comparison with Oman, Qatar and the United Arab Emirates. GeoArabia Special Publication, 4, 503-548.

[45] Alsharhan, A.S. (1994) Albian Clastics in the Western Arabian Gulf Region: A Sedimentological and PetroleumGeological Interpretation. Journal of Petroleum Geology, 17, 279-300. http://dx.doi.org/10.1111/j.1747-5457.1994.tb00135.x

[46] Ebanks, W.J. (1987) Flow Unit Concept-Integrated Approach to Reservoir Description for Engineering Projects. AAPG Meeting Abstracts, 1, 521-522.

[47] Abbaszadeh, M., Fujil, H. and Fujimoto, F. (1996) Permeability Prediction by Hydraulic Flow Unit's Theory and Applications. SPE Formation Evaluation, 11, 263-271. http://dx.doi.org/10.2118/30158-PA

[48] Porras, J.C. and Campos, O. (2001) Rock Typing: A Key Approach for Petrophysical Characterization and Definition of Flow Units, Santa Barbara Field Eastern Venezuela Basin. Society of Petroleum Engineers, Paper No. 69458. http://dx.doi.org/10.2118/69458-ms

[49] Uguru, C.I., Onyeagoro, U.O., Lin, J., Okkerman, J. and Sikiru, I.O. (2005) Permeability Prediction Using Genetic Unit Averages of Flow Zone Indicators (FZIs) and Neural Networks. Shell Petroleum Development Company of Nigeria limited, Society of Petroleum Engineers, Paper No. 98828. http://dx.doi.org/10.2118/98828-ms

[50] Amaefule, J.O., Altunbay, M., Tiab, D., Kersey, D.G. and Keelan, D.K. (1993) Enhanced Reservoir Description; Using Core and Log Data to Identify Hydraulic (Flow) Units and Predict Permeability in Uncored Intervals/Wells: Formation Evaluation and Reservoir Geology. Proceedings of the Society of Petroleum Engineers Annual Conference, Houston, 3-6 October 1993, 205-220. http://dx.doi.org/10.2118/26436-ms

[51] Soto, R. and Garcia, J.C. (2001) Permeability Prediction Using Hydraulic Flow Units and Hybrid Soft Computing Systems. SPE Paper No. 71455. http://dx.doi.org/10.2118/71455-ms

[52] Gomes, J.S., Riberio, M.T., Strohmenger, C.J., Negahban, S. and Kalam, M.Z. (2008) Carbonate Reservoir Rock Typing the Link between Geology and SCAL. SPE Paper No. 118284. http://dx.doi.org/10.2118/118284-ms

[53] Al-Ajmi, F.A. and Holditch, S.A. (2000) Permeability Estimation Using Hydraulic Flow Units in a Central Arabia Reservoir. SPE Paper No. 63254. http://dx.doi.org/10.2118/63254-ms

[54] Kozeny, J. (1927) Uber Kapillare Leitung des Wassersim Boden Stizurgsberichte. Royal Academy of Science, Vienna, Proceedings, Class I, 136, 271-306.

[55] Carmen, P.C. (1937) Fluid Flow through Granular Beds. Transactions of AIChE, 15, 150-166.

[56] Qorashi, M. and Arian, M. (2011) Tectonics of Iran. Geologic Survey of Iran, Tehran, 336 p.

[57] Arian, M. and Aram, Z. (2014) Relative Tectonic Activity Classification in the Kermanshah Area, Western Iran. Solid Earth, 5, 1277-1291. http://dx.doi.org/10.5194/se-5-1277-2014 
[58] Pazhoohan, M., Arian, M., Ghorashi, M. and Khosrotehrani, K. (2014) A Study of Drainage Pattern Responses to Active Tectonics in Tadvan Region, SW Iran. Geodynamics, 1, 36-41.

[59] Rahimi, N. and Arian, M. (2014) Tectonic Geomorphplogy of Hamedan-Sosangerd Region, West Iran. Advances in Environmental Biology, 8, 119-124.

[60] Arian, M. and Qorashi, M. (2006) The Movement Potential Evaluation of the Major Quaternary Faults in Alborz-Central Iran Border Zone, from the East of Tehran to the East of Semnan. Journal of Geosciences, Geological Survey of Iran, 15, 184-188.

[61] Poroohan, N., Poukermani, M. and Arian, M. (2009) An Assessment on Correlations of Seismotectonic Parameters Preceding and Following Roudbar-Manjil Earthquake (Gilan, North of Iran). Australian Journal of Basic \& Applied Sciences, 3, 2643-2652.

[62] Sorbi, A., Arian, M. and Pourkermani, M. (2011) The Application of Geomorphic Indices to the Assessment of Relative Tectonic Activity Levels in Tehran Quadrangle. Journal of the Earth, 6, 1-9.

[63] Arian, M., Toudeshki, V.H. and Noroozpour, H. (2011) Active Tectonics of Qezel Ozan River Basin, NW Iran. Journal of Applied Environmental and Biological Sciences, 1, 291-295.

[64] Arian, M., Pourkermani, M., Sistanipour, A. and Noroozpour, H. (2011) Seismicity and Fault Segmentation of BafqBaghin Fault System (Central Iran). Journal of Applied Environmental and Biological Sciences, 1, 382-396.

[65] Arian, M. (2013) Physiographic-Tectonic Zoning of Iran’s Sedimentary Basins. Open Journal of Geology, 3, 169-177. http://dx.doi.org/10.4236/ojg.2013.33020

[66] Edgell, H.S. (1996) Salt Tectonism in the Persian Gulf Basin. Geological Society, Special Publications, 100, $129-151$. http://dx.doi.org/10.1144/GSL.SP.1996.100.01.10 